\title{
Universiteit
}

Leiden

The Netherlands

\section{Closing yield and harvest area gaps to mitigate water scarcity related to China's rice production}

Lan, K.; Chen, X.; Ridoutt, B.G.; Huang, J.; Scherer, L.A.

\section{Citation}

Lan, K., Chen, X., Ridoutt, B. G., Huang, J., \& Scherer, L. A. (2021). Closing yield and harvest area gaps to mitigate water scarcity related to China's rice production. Agricultural Water Management, 245. doi:10.1016/j.agwat.2020.106602

Version: $\quad$ Publisher's Version

License: $\quad$ Licensed under Article 25fa Copyright Act/Law (Amendment Taverne)

Downloaded from: https://hdl.handle.net/1887/3251043

Note: To cite this publication please use the final published version (if applicable). 
Research paper

\title{
Closing yield and harvest area gaps to mitigate water scarcity related to China's rice production
}

\author{
Kang Lan ${ }^{\text {a, } 1}$, Xin Chen ${ }^{\text {a, } 1}$, Bradley G. Ridoutt ${ }^{\text {b,c }}$, Jing Huang ${ }^{\text {a, }}$, Laura Scherer ${ }^{\mathrm{d}}$ \\ ${ }^{a}$ College of Life Science and Engineering, Southwest University of Science and Technology, Mianyang 621010, China \\ ${ }^{\mathrm{b}}$ Agriculture and Food, Commonwealth Scientific and Industrial Research Organisation (CSIRO), Victoria 3169, Australia \\ ${ }^{\mathrm{c}}$ Department of Agricultural Economics, University of the Free State, Bloemfontein 9300, South Africa \\ ${ }^{\mathrm{d}}$ Institute of Environmental Sciences (CML), Leiden University, Leiden 2333 CC, The Netherlands
}

\section{A R T I C L E I N F O}

Handling Editor - Dr. N. Jovanovic

\section{Keywords:}

Yield gap

Cropping intensity

Water footprint

Cropping redistribution

Sustainable agriculture

Freshwater use

\begin{abstract}
A B S T R A C T
Over the past decades, China's rice production area has experienced a substantial change in spatial distribution that has exacerbated national freshwater scarcity. To support the development of guidelines for sustainable water use in rice cropping, this study explores the potential for achieving a downscaled freshwater use boundary with high spatial resolution while maintaining China's current production levels. We found that, to operate within the boundary, which was defined using a water scarcity index, national irrigation water use for rice cropping should reduce by $10 \%$ in water-scarce regions, implying a $10 \%$ loss in national rice production without further intervention. However, using scenario analysis, we found that the production losses can be reduced to approximately $7 \%$ by closing yield gaps, and fully compensated by closing harvest area gaps in water-rich regions. The closing of both the yield and harvest area gaps allows an increase of 6.9 million metric tons of rice (3\% of the national production). The water-rich regions which are suitable for double-rice systems show a high potential to increase rice production. The spatial redistribution of rice production under these scenarios resulted in a reduction in the national water-scarcity footprint related to rice cropping of $52-55 \%$. These results demonstrate that, to reach the downscaled water use boundary, national redistribution of rice production is necessary and urgent. Our study provides detailed spatial information to support water and land use decisions.
\end{abstract}

\section{Introduction}

Freshwater is one of the most important resources on Earth. Although it appears that current global blue water consumption (surface and groundwater) is within the freshwater use boundary (Steffen et al., 2015), there is a growing demand to downscale the boundary, as water scarcity is a local or regional phenomenon (Huang et al., 2020; Ridoutt and Pfister, 2010a). It has been identified that the spatial water consumption pattern rather than the absolute shortage requires further assessment to reduce the pressure humanity puts on freshwater because major parts of global freshwater withdrawals occur in water-stressed regions (Ridoutt and Pfister, 2010a). Agriculture is the most waterintensive sector, accounting for more than $85 \%$ of the world's water consumption (Döll and Siebert, 2002; Rodda, 2004). At present, many of the world's intensive agricultural production areas, such as the North
China plain (Zhang et al., 2018) and California in the USA (Diffenbaugh et al., 2015), are facing water scarcity. Irrigation has exacerbated the problem and caused serious environmental impacts (e.g., over-depletion of groundwater and increased surface runoff) (Sun et al., 2015; Tian et al., 2009). It is imperative to optimize the spatial pattern of global irrigation consumption to meet the goals of food security and sustainable water use (Davis et al., 2017).

Rice is one of the staple grain crops in China. China produces $28 \%$ of the global rice supply and is self-sufficient currently (Deng et al., 2019). As a water-intensive crop, almost all the rice cropping systems in China are irrigated (You, 2012). In recent decades, China's rice production has experienced a substantial spatial change, and that change has exacerbated China's national water scarcity because of the mismatch in the spatial and temporal distributions of arable land and water resources in China (Huang et al., 2020).

\footnotetext{
Abbreviations: AEZ, agro-ecological zone; WSI, water scarcity index; WSF, water-scarcity footprint.

* Corresponding author.

E-mail address: huang.jing@swust.edu.cn (J. Huang).

1 These authors contributed equally to this work.
} 
Few studies have investigated the associated environmental impacts and measures for mitigation, particularly with regard to freshwater consumption. Davis et al. (2017) found that the global redistribution of crops would ensure food security while reducing water consumption. Our previous study determined that to meet a downscaled water use boundary, which was defined by a water scarcity index (WSI) (Pfister et al., 2009) derived from the water consumption-to-availability ratio, China's national rice production would need to be reduced by $6 \%$ if the yield gap is not closed in water-rich regions (Huang et al., 2020). However, that study was based on county-level data with low spatial resolution. Those results require further assessment with detailed spatial information. In addition, that study only evaluated balancing rice production from the perspective of closing the yield gap. Yu et al. (2017) found that closing the harvest area gap, which was defined as the harvest area that can be gained if existing croplands are harvested as frequently as possible, is another effective measure to promote China's grain production. It is reported that there is substantial potential to increase rice cropping via the conversion of single-rice systems to double-rice systems in southern China (Deng et al., 2019). To date, the environmental implications of closing China's harvest area gaps have not been assessed, and those of closing yield gaps have only been assessed at a coarse scale. To fill these gaps, we aim to assess the potential of rice redistribution in China at a high spatial resolution by considering a downscaled water use boundary and the closing of both yield and harvest area gaps.

In this study, three scenarios (i.e., closing yield gaps, closing harvest area gaps, and closing both yield and harvest area gaps) were designed to redistribute China's rice production to meet a downscaled water use boundary with a high spatial resolution of 5 arc-minutes. The AquaCrop model (Raes et al., 2009; Steduto et al., 2009) was applied to simulate rice yield and irrigation water consumption, which were then used to calculate yield gaps and water-scarcity footprints (WSFs), which are an indicator of the potential environmental impacts from water scarcity (Ridoutt and Pfister, 2010a). We compared the WSFs before and after the redistribution of rice production and examined the balance of rice production under the different scenarios. In this way, we explored whether China can remain within water sustainability limits while maintaining the current level of rice production. Our study aims to provide evidence that enables policies to set agricultural water use priorities by redistributing rice production and promoting rice production in suitable regions (a framework figure is available in Supplementary Information, SI Fig. S1).

\section{Methods}

\subsection{Crop model and data sources}

We applied the FAO AquaCrop model (http://www.fao.org /aquacrop) to simulate rice yield and irrigation water consumption across China (5 arc-minutes). AquaCrop was originally developed as a single-point, field-based model that focused on the simulation of crop yield responses to water (Raes et al., 2009; Steduto et al., 2009). Its application has been globally tested in various agricultural systems (Vanuytrecht et al., 2014). Through field experiments, the AquaCrop model has been calibrated and validated for cropping systems in China (Huang et al., 2020). To advance the application of AquaCrop to national-scale spatiotemporal simulations, we managed the inputs and outputs of AquaCrop using a geospatial tool called GeoSim (Thorp and Bronson, 2013) that was modified to work effectively with AquaCrop nationwide in China (Huang et al., 2019b).

The raster maps of yield, production, physical area and harvest area of rice in 2010 (averaged from 2009 to 2011) were obtained from the Spatial Production Allocation Model (International Food Policy Research Institute, 2019), representing the actual rice production. The model downscales the crop production statistics originally reported by geographically-aggregated administrative units (counties), considering any prior knowledge about the spatial distribution of crops (e.g., satellite-derived land cover images, crop suitability, irrigation and population density). The model outputs were validated by various data sources and are considered as the most disaggregated spatial data of crops on a global scale (You et al., 2014).

Daily climate data from 729 weather stations in the rice cropping regions as well as crop parameters (e.g., sowing date, sowing density, and growth period) from 2009 to 2011 were obtained from the National Meteorological Information Centre (http://data.cma.cn). Soil data from the Harmonized World Soil Database (Wieder et al., 2014) were used to distinguish soil textures. The key indicators of each soil hydraulic parameter and other crop parameters are presented in our previous study (Huang et al., 2020). The initial soil moisture content of rice was set at saturation because paddy fields are generally prepared to be saturated before transplanting. As almost all rice cropping systems are irrigated in China (You, 2012), we modeled rice yield and water consumption by applying the "Determination of Net Irrigation Requirement" option in AquaCrop, which designates the addition of a small amount of water per day to the soil profile for full irrigation when root zone water consumption exceeds the specified threshold. The threshold was set to $10 \%$ of readily available soil water, which can produce high yields while avoiding irrigation water waste (Lu et al., 2009; Peng et al., 2006). We did not consider the possible stress factors (e.g., nutrient deficiencies and soil salinization) that could lead to yield loss. Therefore, the simulated rice yield can be considered as the potential yield. The processing of input data for AquaCrop modeling and AquaCrop's implementation in GeoSim were conducted as described in our previous study (Huang et al., 2019b). Finally, the simulated results of rice yield and irrigation water requirements from 2009 to 2011 were obtained and averaged at the grid-cell level to represent the yield and irrigation water consumption in 2010 .

\subsection{Yield and harvest area gap assessment}

Over the past decades, the term yield gap has been widely used in the literature to indicate the difference between actual and potential yields (Lobell et al., 2009; Mueller et al., 2012). The yield-gap analysis provides a way to estimate the untapped production potential by estimating the difference between current agricultural yield and the potential yield that can be achieved when yield losses due to factors such as nutrient deficiencies, pests, and diseases are minimized (Lobell et al., 2009). In this study, the potential rice yields were obtained from AquaCrop as described in Section 2.1. Previous studies have illustrated that current farm yields tend to stagnate at $75-80 \%$ of the potential yield due to the decline in the return on investment of additional inputs (Deng et al., 2019; Lobell et al., 2009). We set the exploitable yield to $80 \%$ of the potential yield in this study. The yield gap was calculated as:

$Y_{\text {gap }}=Y_{\text {potential }} \cdot 80 \%-Y_{\text {actual }}$

where $Y$ is the yield $\left(\mathrm{kg} \mathrm{ha}^{-1}\right)$. Analogous to the yield gap, the harvest area gap was defined as the harvest area that can be gained if existing croplands are harvested as frequently as possible based on their potential for multi-cropping (Yu et al., 2017). It has been determined that there is substantial potential to increase the harvest area gap based on existing croplands without cropland expansion in China or globally (Wu et al., 2018; Yu et al., 2017). The major potential for increasing China's rice harvest area exists in the warm climates of southern regions, where double-rice cropping (i.e., two rice crops per year planted and harvested in the same field) is possible (Deng et al., 2019). By applying the spatial boundary of double-rice systems identified by a previous study (Deng et al., 2019), we calculated the harvest area gap ( $H A_{\text {gap }}$, ha) by applying the cropping frequency (2):

$H A_{\text {gap }}=A_{\text {physical }} \cdot 2-H A_{\text {actual }}$

The results of yield and harvest area gaps were presented in a raster map with the boundaries of China's agro-ecological zones (AEZs, Fig. 1), 


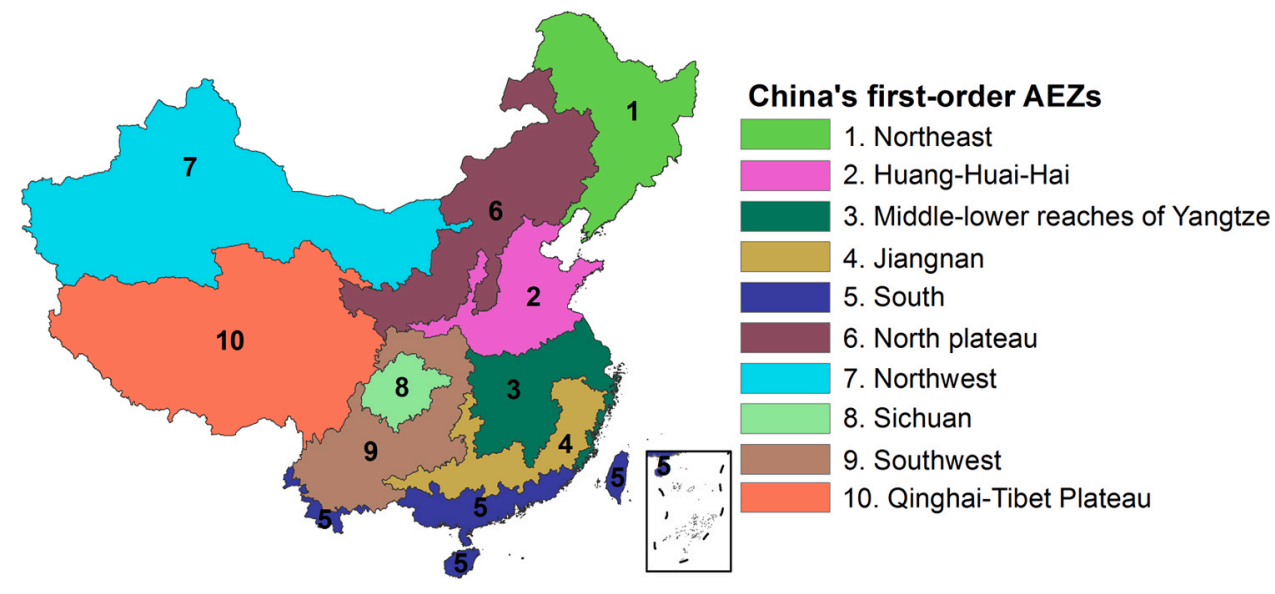

Fig. 1. China's first-order agro-ecological zones (AEZs). The number of the AEZ represents the code linked to its name (Liu and Chen, 2005).

which are defined based on factors such as climatic, soil and landform characteristics (Liu and Chen, 2005).

Although yield and harvest area gaps may exist in many regions, it would be environmentally harmful to increase rice production in waterscarce regions. Thus, in this study, we only consider the yield and harvest area gaps in water-rich regions. The water-scarce and water-rich regions were defined based on a downscaled water use boundary and are described in Section 2.3.

\subsection{Downscaling the freshwater use boundary}

The originally proposed freshwater use boundary provides a global benchmark of blue water consumption (Rockström et al., 2009). The absolute benchmark does not consider the water scarcity background or spatial heterogeneity of water scarcity (Huang et al., 2020). To reflect the spatial heterogeneity of regional water scarcity as reflected by water consumption and water availability, we downscaled the water boundary by applying a WSI (Pfister et al., 2009). A WSI, which links water consumption to potential impacts from water scarcity, is related to the ratio of freshwater consumption to hydrological availability and ranges from 0.01 to 1 . We calculated the WSIs in 2010 (averaged from 2009 to 2011) following the method of Scherer and Pfister (2016), which has calculated the global WSIs as consumption-weighted average of monthly WSIs for the decades 1981-1990 and 2001-2010 at a resolution of 30 arc-minutes. Applying the data of water consumption, water availability and precipitation from the same global datasets during 2009-2011, we calculated the average monthly WSIs for the years of 2009-2011 in China. The primary 30 arc-minute data were disaggregated by bilinear interpolation to 5 arc-minutes. The sustainable water use boundary in an area with rice cultivation was defined as the water consumption level that results in a WSI of 0.5, which represents the threshold between moderate and severe water scarcity (Pfister et al., 2009). We then assessed the gap between the water consumption in 2010 and the target at the downscaled water boundary.

First, we obtained the monthly water consumption $\left(W C_{m}\right.$ actual, $\left.\mathrm{m}^{3}\right)$ of all users (i.e., agriculture, industry and domestic sector) in each grid cell in 2010 from global datasets (Scherer and Pfister, 2016). Second, we computed the monthly target water consumption $\left(W C_{m}\right.$ target, $\left.\mathrm{m}^{3}\right)$ by setting the WSI to the threshold of 0.5 . Third, a ratio $(R)$, which reflects the extent to which the current water consumption would be reduced or increased to reach the target, was calculated as:

$R=\min _{m \in \text { months }}\left(W C_{m, \text { target }}-W C_{m, \text { actual }}\right) / W C_{m, \text { actual }}$

Using the minimum ratio among the months was intended to achieve the sustainability target even in the month with the most severe water scarcity. The $R$ was then applied to determine the irrigation water consumption gap for current rice production by the following processes.

First, we assessed the actual irrigation water consumption ( $I_{\text {actual }}$, $\mathrm{m}^{3}$ ) for rice in each grid cell:

$I_{\text {actual }}=I_{k g} \cdot P_{\text {actual }}$

where $I_{k g}\left(\mathrm{~m}^{3} \mathrm{~kg}^{-1}\right)$ is the irrigation water consumption per kilogram of rice in each grid cell based on the irrigation water consumption and rice yield obtained from AquaCrop (see Section 2.1). The $P_{\text {actual }}(\mathrm{kg})$ is the actual rice production in each grid cell. The gap $\left(I_{\text {gap }}, \mathrm{m}^{3}\right)$ between the actual and target irrigation water consumption was then calculated by applying $R$ :

$I_{\text {gap }}=I_{\text {actual }} \cdot R$

We assumed that in limiting the water consumption to reach a sustainable water use boundary (WSI $=0.5$ ), all the water users, including rice production, should have equal responsibility. A negative $I_{g a p}$ indicates that the area is a water-scarce region that must reduce irrigation water consumption to reach the boundary, whereas a positive value indicates that the area is a water-rich region, which has a certain potential to increase irrigation.

\subsection{Rice redistribution under water constraints}

To meet the downscaled water use boundary, rice production in some water-scarce regions should be reduced, whereas some water-rich regions have the potential to increase production. The gap in rice production $\left(P_{\text {gap }}, \mathrm{kg}\right)$ associated with the water consumption gap was calculated as:

$P_{\text {gap }}=I_{\text {gap }} / I_{k g}$

Analogous to $I_{g a p}$ a negative $P_{\text {gap }}$ indicates that the area should reduce rice production, whereas a positive value indicates that the area has a certain potential to increase production. Here, however, the potential for increasing rice production is the highest potential based only on irrigation water availability. The actual production might be constrained by the crop yield and area. Therefore, we further examined the potential of regions with the capacity for additional irrigation water to boost rice production. We did not allow for cropland expansion in the water-rich areas so that the potential for rising rice production would be achieved by closing yield and harvest area gaps. We designed three scenarios of rice redistribution to examine the national balance of rice production needed to reach the water use boundary.

In Scenario 1, we increased rice production in water-rich regions by only closing the yield gap (see Section 2.2). The potential increase in rice production under Scenario $1\left(P_{1, \text { potential }}, \mathrm{kg}\right)$ at the grid-cell level was calculated as: 
$P_{1, \text { potential }}=Y_{\text {potential }} \cdot 80 \% \cdot H A_{\text {actual }}-P_{\text {actual }}$

In Scenario 2, we increased rice production in the water-rich regions by only closing the harvest area gap (see Section 2.2). The potential increase in rice production under Scenario $2\left(P_{2 \text {,potential }} \mathrm{kg}\right)$ at the gridcell level was calculated as:

$P_{2, \text { potential }}=Y_{\text {actual }} \cdot A_{\text {physical }} \cdot 2-P_{\text {actual }}$

In Scenario 3, we increased rice production in the water-rich regions by closing both the yield and harvest gaps (i.e., by maximizing production potential). The potential increase in rice production under Scenario $3\left(P_{3, \text { potential }}, \mathrm{kg}\right)$ at the grid-cell level was calculated as:

$P_{3, \text { potential }}=Y_{\text {potential }} \cdot 80 \% \cdot A_{\text {physical }} \cdot 2-P_{\text {actual }}$

The water- and production-constrained potential $\left(\mathrm{P}_{i, \text { constrained, }} \mathrm{kg}\right)$ for a water-rich region to increase crop production under Scenario $i(i=1$, 2,3 ) was determined by:

$P_{i, \text { constrained }}=\min \left(P_{\text {gap }}, P_{i, p o t e n t i a l}\right)$

The total production under the three scenarios $\left(\mathrm{P}_{i, \text { total }} \mathrm{kg}\right)$ was calculated as:

$P_{i, \text { total }}=P_{i, \text { constrained }}+P_{\text {actual }}$

By integrating the grid cells where rice production should decrease to meet the downscaled water boundary with the grid cells that have the potential to increase rice production, we obtained three raster maps of the rice redistribution under the three scenarios. The actual irrigation, irrigation gap, actual production, and production gap at the grid-cell level were aggregated at the level of China's AEZs for analyzing the regional balance of rice production and water consumption.

\subsection{Water-scarcity footprint assessment}

The WSI was used to calculate the water-scarcity footprint per kilogram of grain $\left(W S F_{k g}, \mathrm{~m}^{3} \mathrm{H}_{2} \mathrm{Oe} \mathrm{kg}^{-1}\right.$ ) following the method developed by Ridoutt and Pfister. (2010b):

$W S F_{k g}=I_{k g} \cdot W S I$

The average WSI from 2009 to 2011 (see Section 2.3) was applied to calculate the $\mathrm{WSF}_{\mathrm{kg}}$ in 2010. For the three scenarios, the WSIs of the water-scarce regions after rice redistribution were supposed to be 0.5 because we assumed that all water users should reduce water consumption to reach the downscaled water boundary. However, it is impossible to assess the exact WSIs in the water-rich regions after rice redistribution as our study only investigated rice production. Therefore, we determined the degree to which water was reduced in the waterscarce regions and then assumed that the water consumption in the water-rich regions required to compensate for that reduction was increased proportionally unless the water boundary was reached earlier. We then recalculated the WSI and WSF per kilogram of grain $\left(W S F_{k g}\right.$, redistributed, $\mathrm{m}^{3} \mathrm{H}_{2} \mathrm{Oe} \mathrm{kg}^{-1}$ ) in the water-rich regions.

The $W F_{2010}\left(\mathrm{~m}^{3} \mathrm{H}_{2} \mathrm{Oe}\right)$ in 2010 was derived from the actual production as:

$W S F_{2010}=W S F_{k g} \cdot P_{\text {actual }}$

Accordingly, the WSF under the three scenarios $\left(W S F_{i}, \mathrm{~m}^{3} \mathrm{H}_{2} \mathrm{Oe}\right)$ for rice redistribution was calculated as:

$W S F_{i}=W S F_{k g, \text { redistributed }} \cdot P_{i, \text { total }}$

The WSFs in 2010 and after redistribution at the grid-cell level were aggregated to the level of China's AEZs.

To compare the spatial variability of WSFs at both the AEZ and national scales, we calculated the coefficients of variation (CVs) of the WSFs as:

$\mathrm{CV}=\sigma / \mu$ where the $\sigma$ is the standard deviation, and $\mu$ is the average of the WSFs.

\section{Results}

\subsection{Yield and harvest area gaps}

The estimated national potential yields ranged from 6.6 to $10.9 \mathrm{t} \mathrm{ha}^{-1}$, while the farm yields varied from 4.3 to $6.7 \mathrm{t} \mathrm{ha}^{-1}$. In the water-rich regions, the area-weighted average potential yield was $7.4 \mathrm{t} \mathrm{ha}^{-1}$, whereas the average farm yield was $6.5 \mathrm{t} \mathrm{ha}^{-1}$. It indicated that the farm yield had already approached the $80 \%$ potential yield threshold. However, the potential yields varied widely among regions and rice cropping systems. The average potential yield of single-rice crops was $7.9 \mathrm{tha}^{-1}$, while that of the double rice crops was $6.9 \mathrm{tha}^{-1}$ for each round of cultivation.

Converting single-rice systems to double-rice systems will increase the annual yield. The annual potential yield from double-rice crops was $13.8 \mathrm{tha}^{-1}$, which is $75 \%$ higher than that of the single rice crop. The exploitable yield gaps (based on $80 \%$ potential yield) in the double-rice systems were $35 \%$ greater than for the single-rice systems (an average of 0.8 versus $0.6 \mathrm{t} \mathrm{ha}^{-1}$ per season, respectively). The exploitable yield gap varied among China's AEZs (Fig. 2). The highest yield gap was found in the Qinghai-Tibet Plateau (an average of $3.6 \mathrm{tha}^{-1}$ ), but this region has a small rice production area (less than 0.01 million ha). The Southwest had a relatively high yield gap of $0.7 \mathrm{t} \mathrm{ha}^{-1}$, followed by Jiangnan $\left(0.5 \mathrm{tha}^{-1}\right)$ and the South $\left(0.4 \mathrm{tha}^{-1}\right)$. However, if the annual doublecropping practices in Jiangnan and the South are taken into consideration, the yield gaps in these AEZs were higher than those in the Southwest. The yield gaps in the middle-lower reaches of Yangtze River basin and in Sichuan were less than $0.1 \mathrm{tha}^{-1}$.

The national harvest area gap was approximately 6.0 million ha, accounting for $21 \%$ of the national rice harvest area in 2010. Considering water availability, the harvest area gap in the water-rich regions was 4.7 million ha (Fig. 3). The middle-lower reaches of the Yangtze River basin had the largest harvest gap (2.0 million ha) followed by Jiangnan (1.3 million ha) and the South (1.1 million ha). The total harvest area gap in the middle-lower reaches of the Yangtze River basin, Jiangnan, and the South accounted for $94 \%$ of the harvest area gap in the water-rich regions.

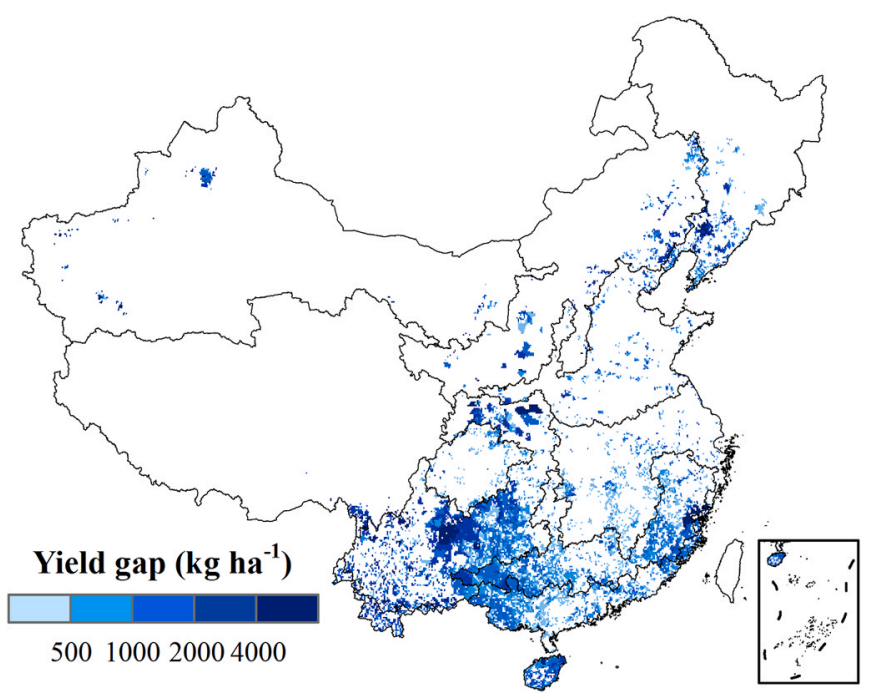

Fig. 2. Exploitable yield gaps in water-rich regions. The black outlines indicate the boundaries of China's first-order AEZs. For the names of the AEZs, please refer to Fig. 1. White indicates no data, no rice or no yield gap. 


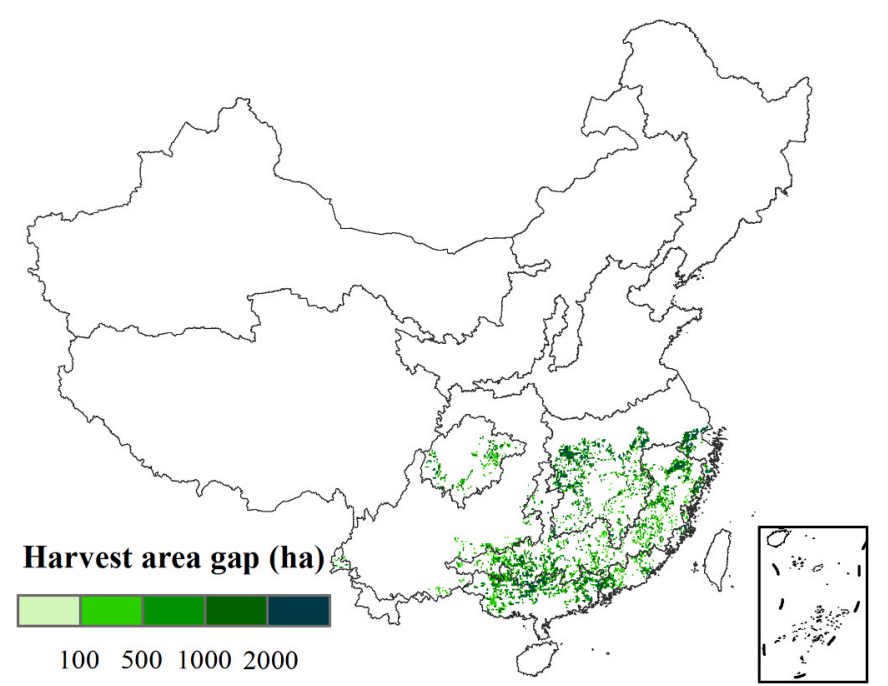

Fig. 3. Harvest area gaps in water-rich regions. The black outlines indicate the boundaries of China's first-order AEZs. For the names of the AEZs, please refer to Fig. 1. White indicates no data, no crop or no harvest area gap.

\subsection{Rice redistribution under water constraints}

The WSIs before rice redistribution (in 2010) were presented in Fig. 4a. WSI varies spatially. The higher WSIs were founded in waterscarce regions, such as the Huang-Huai-Hai and northwestern regions. The WSIs in these regions were close to 1.0. In contrast, the WSIs in some southern and northeastern regions were much less than 0.5. After rice redistribution to reach the downscaled water use boundary (WSI $=0.5$ ), the WSIs higher than 0.5 in water-scarce regions are reduced to be 0.5 ; the WSIs in water-rich regions are still equal to or less than 0.5 , but the WSIs in some regions have been slightly increased because of the increase of rice production (Fig. 4b).

To reach the downscaled water use boundary, the national consumption of irrigation water for rice production would need to be reduced in water-scarce regions by $7.3 \times 10^{9} \mathrm{~m}^{3}$, which is approximately $10 \%$ of the national irrigation water consumption for rice in 2010. The major hotspot regions were in the middle-lower reaches of the Yangtze River basin, Huang-Huai-Hai, the South, and the Northeast, which required $39 \%, 20 \%, 12 \%$ and $10 \%$, respectively, of the total irrigation reduction target (SI, Table S1). The water-rich regions $\left(\right.$ WSI $<0.5$ ) had the potential to increase irrigation by $1.5 \times 10^{12} \mathrm{~m}^{3}$, which is far greater than the reduction target for the water-scarce regions (SI, Table S1). These regions are primarily located in the middlelower reaches of the Yangtze River basin and the Northeast; both regions account for approximately $42 \%$ of the total potential increase in irrigation water. Consequently, there is no absolute national irrigation water shortage for rice production within the water use boundary.

A reduction in irrigation within the water-scarce regions implies that the associated rice production would also be decreased. Based on the current crop yields, the total rice loss in the hotspot regions was estimated at 19.4 million metric tons, which is $10 \%$ of the national production in 2010 (SI, Table S2). The major hotspot regions were in the middle-lower reaches of the Yangtze River basin, the South, and HuangHuai-Hai, which would need to reduce their regional rice production by $41 \%, 18 \%$, and $17 \%$, respectively. However, the potential for increasing irrigation in water-rich regions also makes it possible to increase rice production regionally. Closing the yield gaps (Scenario 1) could compensate for $25 \%$ of the loss in rice production in water-scarce regions (Fig. 5a). In meeting the downscaled water use boundary, the national rice production would decrease by 14.5 million metric tons, which represents $7 \%$ of the national production in 2010 . By closing the harvest area gaps (Scenario 2), national rice production would increase slightly by 1.6 million metric tons, which represents $1 \%$ of the national production (Fig. 5b). By closing both the yield and harvest area gaps (Scenario 3), national rice production would increase by 6.9 million metric tons, which represents $3 \%$ of the national production (Fig. $5 \mathrm{c}$ ). The major increases would occur in Jiangnan (63\%), the middle-lower reaches of Yangtze River basin $(60 \%)$, and the South $(26 \%)$, whereas the production in Huang-Huai-Hai, the North plateau, and the Northeast would decrease by $48 \%, 5 \%$ and $5 \%$, respectively.

\subsection{Water-scarcity footprints under different scenarios}

The national WSF for rice production in 2010 was 16.2 billion $\mathrm{m}^{3}$ $\mathrm{H}_{2} \mathrm{Oe}$, whereas the total WSFs after redistribution were 7.3 (S1), 7.7 (S2) and 7.8 billion $\mathrm{m}^{3}$ (S3) (Fig. 6). Compared with the total WSF in 2010, the total WSFs under S1, S2 and S3 decreased by $55.1 \%, 52.4 \%$ and $51.6 \%$, respectively. The primary contributors to the decrease in all scenarios were the middle-lower reaches of the Yangtze River basin and
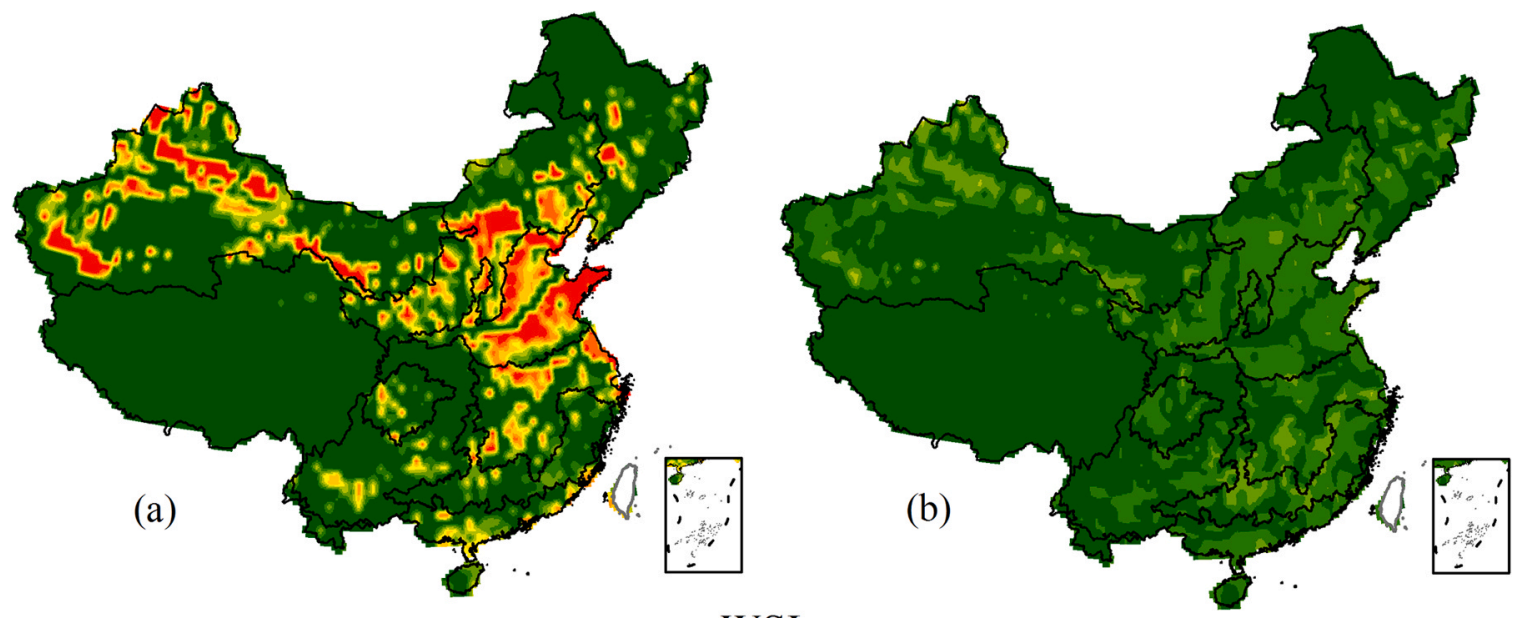

WSI

0.01

Fig. 4. Water scarcity index (WSI) before and after rice redistribution. (a) WSI before redistribution, and (b) WSI after redistribution. White indicates no data. 

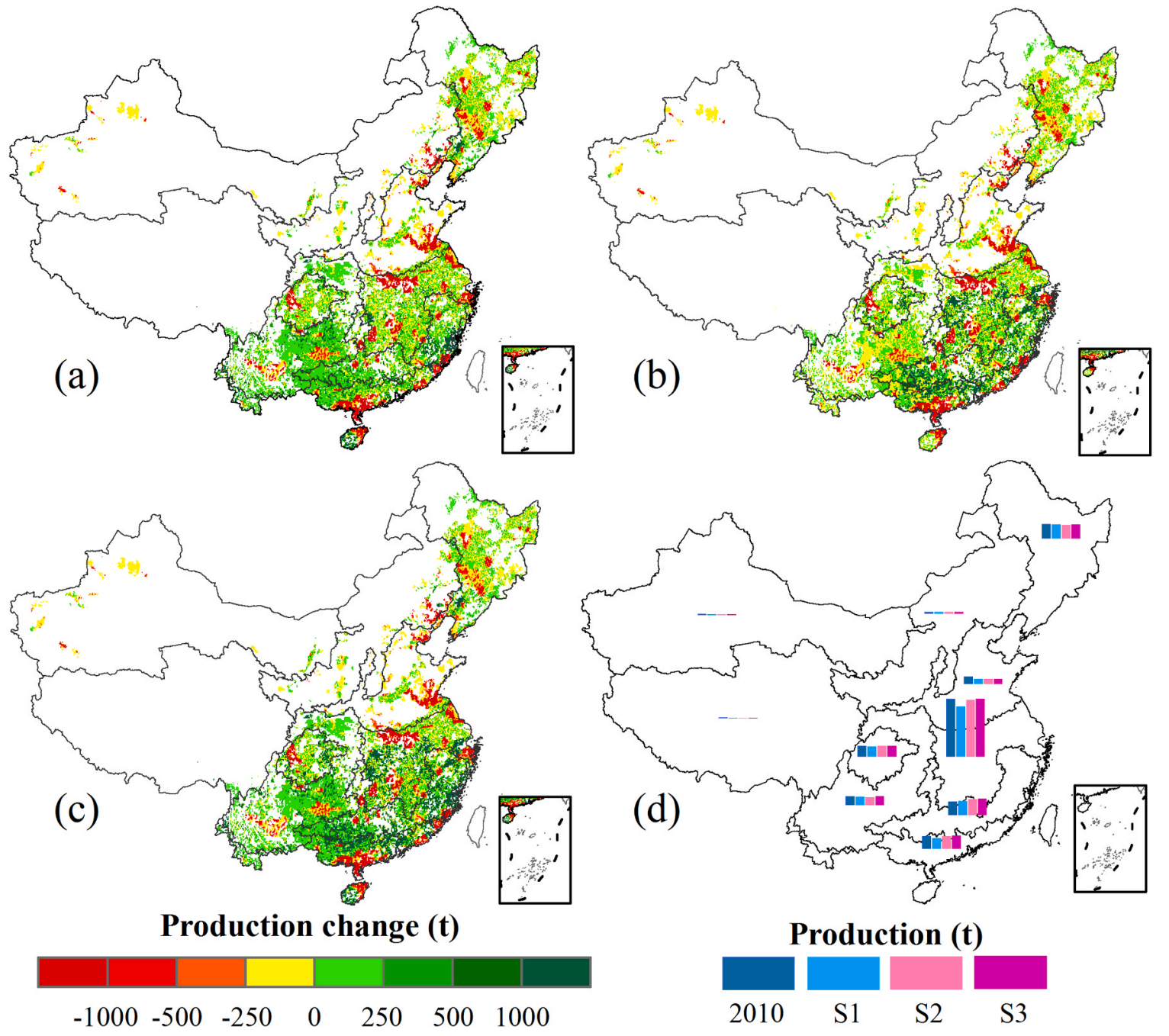

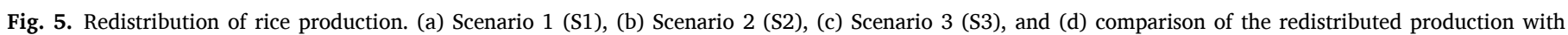
production in 2010 at the AEZ level. The black outlines indicate the boundaries of China's first-order AEZs. For the names of the AEZs, please refer to Fig. 1.

Huang-Huai-Hai. In Scenario 1, the middle-lower reaches of the Yangtze River basin, Huang-Huai-Hai, the South and the Northeast represented $56.1 \%, 15.3 \%, 8.1 \%$ and $7.7 \%$ of the total decrease, respectively. Under Scenario 2 , these zones represented $55.6 \%, 16.0 \%, 7.9 \%$ and $8.3 \%$ of the decrease; whereas under Scenario 3, they represented 56.2\%, $16.3 \%$, $7.8 \%$ and $8.2 \%$ of the decrease.

The coefficients of variation (CVs) of the WSFs across the AEZs and the country are presented in Table 1 . Under the three scenarios, the CVs of the WSFs at the country level were 2.08 (S1), 2.07 (S2) and 2.04 (S3), which are lower than the CV of 2.60 in 2010. Among the major AEZs for rice production, the $\mathrm{CV}$ in the Northeast, Jiangnan, the South and the middle-lower reaches of the Yangtze River basin decreased substantially after redistribution, whereas the CV in Huang-Huai-Hai and the Southwest slightly increased after redistribution. The South was the region with the greatest decrease in the CV after redistribution, from 4.06 to 1.77 (S1), 1.71 (S2) and 1.67 (S3). The WSF of Qinghai-Tibet Plateau is the lowest because rice production in the region is much lower than the other regions. The $\mathrm{CV}$ of the region is higher than of other regions because of the large spatial variations in local water scarcity and rice cropping systems.

\section{Discussion}

\subsection{Comparison with other studies}

The national farm rice yield in 2010 was approximately $6.5 \mathrm{t} \mathrm{ha}^{-1}$. Although a national average yield gap of $3.0 \mathrm{t} \mathrm{ha}^{-1}$ was found by Deng et al. (2019), farm yields typically stagnate in many regions due to numerous factors, such as resource availability and diminishing returns from inputs. Considering the sustainable water use limit, we estimated the yield gaps in water-rich regions. Our estimated average yield potential $\left(7.4 \mathrm{tha}^{-1}\right)$ in the water-rich regions was lower than the national average potential $\left(9.8 \mathrm{tha}^{-1}\right.$ ) reported by Deng et al. (2019). This difference might be the result of factors such as the use of different time series, spatial resolutions and model choices. In addition, as mentioned in our previous study, the AquaCrop modeling is subject to a range of uncertainties, such as the lack of detailed national datasets on irrigation practices and soil fertility (Huang et al., 2020). However, both studies found that the average farm yield approached the potential threshold and that the potential yields varied widely among regions and rice cropping systems. In addition, both studies identified that double-rice systems have higher yield gaps than single-rice systems. Identifying the critical factors, to which the modeled results of water consumption and crop yield are most sensitive, would allow further improving the results in future work.

To our knowledge, the harvest area gap of rice has not previously 

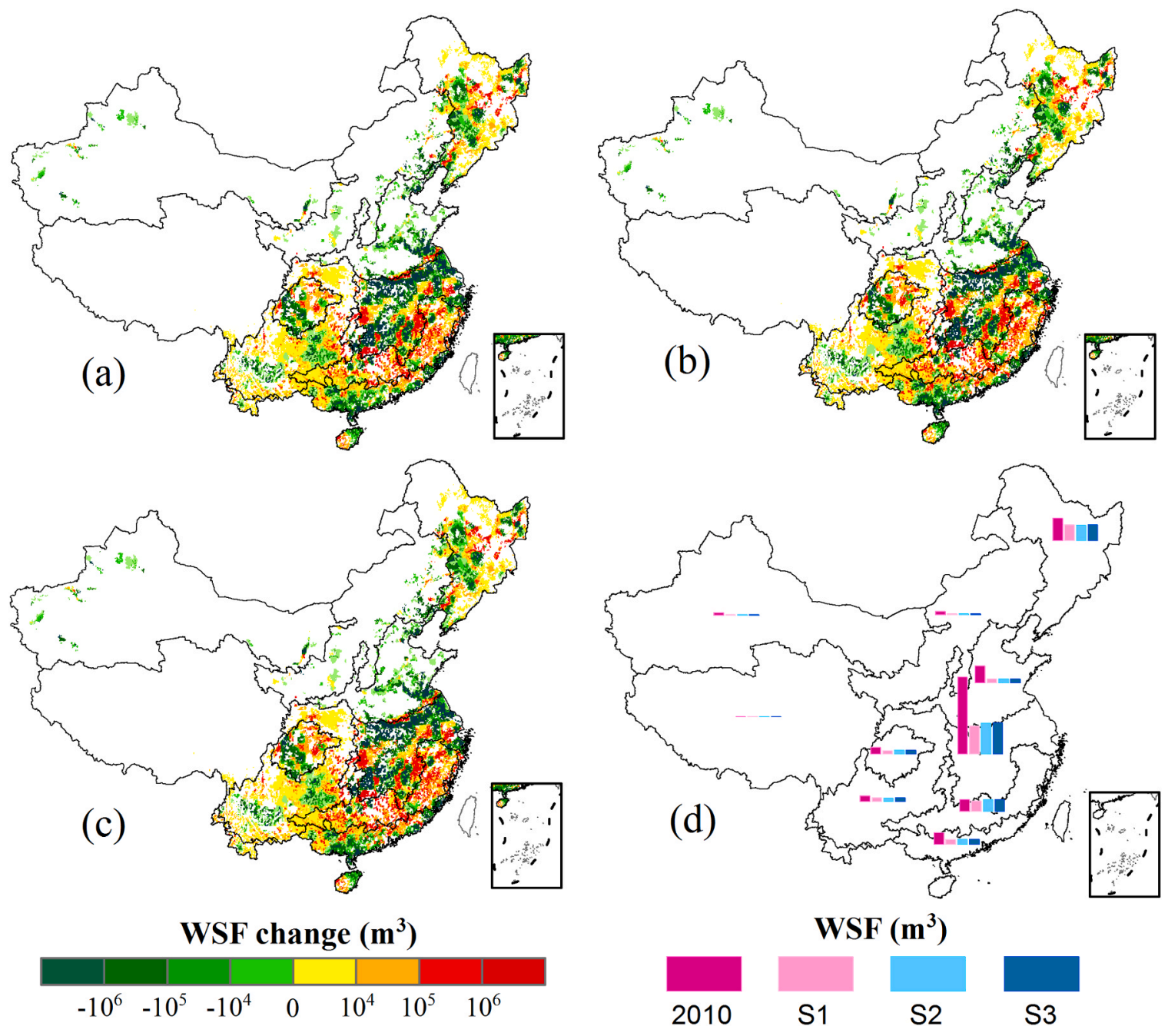

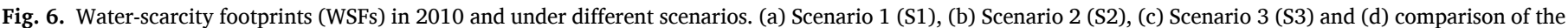

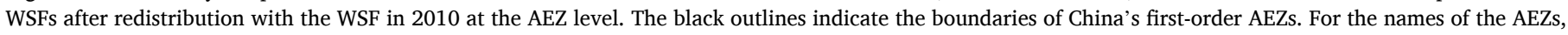
please refer to Fig. 1.

Table 1

Coefficients of variation (CVs) of water-scarcity footprints (WSFs) at the AEZ and country levels.

\begin{tabular}{|c|c|c|c|c|c|}
\hline \multirow[t]{2}{*}{ Region } & \multirow{2}{*}{$\begin{array}{l}\text { WSF in } 2010 \\
\left(\mathrm{~m}^{3}\right)\end{array}$} & \multicolumn{4}{|l|}{$\mathrm{CV}$} \\
\hline & & 2010 & S1 & S2 & S3 \\
\hline Northeast & $2.3 \times 10^{9}$ & 2.69 & 2.57 & 2.61 & 2.57 \\
\hline Huang-Huai-Hai & $1.7 \times 10^{9}$ & 2.43 & 2.44 & 2.45 & 2.44 \\
\hline $\begin{array}{l}\text { Middle-lower reaches of } \\
\text { Yangtze }\end{array}$ & $7.9 \times 10^{9}$ & 1.51 & 1.26 & 1.28 & 1.27 \\
\hline Jiangnan & $1.2 \times 10^{9}$ & 2.61 & 1.54 & 1.52 & 1.49 \\
\hline South & $1.2 \times 10^{9}$ & 4.06 & 1.77 & 1.71 & 1.67 \\
\hline North plateau & $3.5 \times 10^{8}$ & 3.06 & 2.53 & 2.58 & 2.53 \\
\hline Northwest & $2.5 \times 10^{8}$ & 3.00 & 3.20 & 3.22 & 3.20 \\
\hline Sichuan & $6.8 \times 10^{8}$ & 2.16 & 1.13 & 1.12 & 1.12 \\
\hline Southwest & $5.8 \times 10^{8}$ & 4.38 & 3.12 & 3.28 & 3.12 \\
\hline Qinghai-Tibet Plateau & $7.7 \times 10^{4}$ & 4.80 & 5.13 & 4.61 & 5.13 \\
\hline Country & $1.6 \times 10^{10}$ & 2.60 & 2.08 & 2.07 & 2.04 \\
\hline
\end{tabular}

Note: S1: Scenario 1, S2: Scenario 2, S3: Scenario 3. The number of the AEZ represents the codes linked to their names (see Fig. 1).

been estimated using such a high spatial resolution at the national scale. This impeded conducting a detailed comparison with other studies. Yu et al. (2017) found that the rice-dominated regions, including the Lower Yangtze and the southern regions (corresponding to the AEZs of the South and Jiangnan), had the highest attainable harvest area gap, accounting for the majority of the national harvest area gap. That finding is consistent with our results that the major harvest area gaps for rice occurred in the middle-lower reaches of the Yangtze River basin, Jiangnan, and the South.

Our previous study found that closing the yield gap (reaching $80 \%$ of the potential yield) in water-rich regions can fully compensate for the rice loss in water-scarce regions that is required to reach the downscaled water use boundary (Huang et al., 2020). This study found that a loss of $7 \%$ of national production would occur if closing only the yield gaps in water-rich regions was considered. The inconsistency between these two studies might be explained by the following factors. First, the previous assessment was conducted at the county scale (approximately 2900 counties), whereas this study was performed at a grid-cell scale with a resolution of 5 arc-minutes. The low spatial resolution of the previous study led to an overestimation of the area of water-rich regions. The total harvest area in the water-rich regions in the previous study is $14 \%$ higher than that of this study. This higher harvest area led to a higher production estimate when closing the yield gaps in the water-rich regions. However, the most recent data available in the Spatial Production Allocation Model with a high spatial resolution is for 2010, which precluded a high spatial resolution assessment for 2015. Second, the different time series (2015 versus 2010) also led to differences in a number of input variables (e.g., the climate data applied to the AquaCrop modeling). Third, the previous study estimated the target water 
consumption by always aiming at the downscaled water use boundary even if it implied an overall increase in national water consumption, whereas this study maintained the same level of water consumption at the national level after crop redistribution. Thus, the reduction targets and potential increase in regional irrigation water and associated production differ between the two studies. In general, we believe that the results obtained in this study, which are based on more detailed spatial information to reveal the spatial variations on rice performance, are more reliable.

\subsection{Limitations and implications}

It has been broadly recognized that it is necessary to downscale the freshwater use boundary at the regional scale (Huang et al., 2020; Ridoutt and Pfister, 2010b; Steffen et al., 2015). However, few studies have explored how to achieve a downscaled water boundary while ensuring food security. Here, we downscaled the water boundary by applying the water scarcity index, which considers the water scarcity background as reflected by both water consumption and water availability. We set the sustainable water use boundary at a WSI of 0.5 indicating the expert judgment of the threshold between moderate and severe water scarcity (Pfister et al., 2009). However, for future work, the value of 0.5 should be further assessed according to different background and goals of regional water use. In addition, the calculation of WSI in this study was based on the data from 2009 to 2011. The indicator should be updated to account for changes in temperature and precipitation in future work. Also, it is valuable for future work to identify the critical factors which increased the WSIs in the past decades.

Based on the WSI-defined downscaled water use boundary, we assessed the gap between the actual and target irrigation water consumption by applying the ratio (R) (Eqs. 3 and 5). Due to the lack of data and the complexity to allocate distinct responsibilities, we calculated the ratio for all the water users (all sectors and crops), assuming that all the water users, including rice production, are equally responsible to limit their water consumption to reach the sustainable boundary. The consideration of the minimum ratio among the months aimed to achieve the sustainability target even in the month with the most severe water scarcity. Thus, it might underestimate the potential to increase irrigation in water-rich regions, while overestimating the need to reduce irrigation in water-scarce regions. Nevertheless, our results show substantial potential to increase irrigation water in water-rich regions, which exceeds the reduction target in the water-scarce regions. Our conclusion that there is no absolute national irrigation water shortage for rice production within the water use boundary remains reliable. However, the actual increase in irrigation water depends on many factors, such as the availability of infrastructure and system efficiency, which require further assessment.

As an irrigation-intensive crop, rice production has generated the highest water scarcity of China's three stable grain crops (i.e., rice, wheat and maize) as reflected by the water-scarcity footprint indicator (a national average of $0.15,0.13$ and $0.05 \mathrm{~m}^{3} \mathrm{H}_{2} \mathrm{Oe} \mathrm{kg}{ }^{-1}$ for rice, wheat and maize, respectively) (Huang et al., 2020). Many studies have focused on water-saving measures for rice cropping from the perspective of breeding drought-tolerant varieties and improving soil quality and farm management practices (Mbava et al., 2020; Zwart and Bastiaanssen, 2004). Few studies have examined the spatial patterns of water consumption for national rice cropping, which may put pressure on China's freshwater when rice production occurs in regions of high water scarcity. China's rice production has experienced a substantial spatial change in recent decades (Liu et al., 2013). Aside from some driving factors, such as urbanization, improvements in irrigation and changes of land use policy, climate change has been identified as an important driver of the spatial change in rice production (Li et al., 2015; Liu et al., 2015). It has been reported that approximately 37 billion ha ( $4 \%$ of the national land area) in northern regions has become suitable for rice cultivation due to climate change over the past three decades, and $18.2 \%$ of the increase in rice cropping area matches the pattern of climate change (Liu et al., 2015). The spatial change in rice production has substantially increased the total water-scarcity footprint of national rice production, and the increase is primarily related to production expansion in the Northeast (Huang et al., 2020). This study found that to meet the downscaled water use boundary, the irrigation water in the water-scarce regions in the Northeast must be reduced by $10 \%$ of the national target of irrigation reduction. This finding indicates that regional policies on water management and food production should carefully consider spatial variation in water scarcity, particularly in the context of climate change. Warmer temperatures might allow the expansion of rice cropping but may also exacerbate local water scarcity.

To reach the downscaled water use boundary, a national redistribution of rice production is necessary and urgent. Rice redistribution under our scenarios could considerably reduce the national waterscarcity footprint by $52-55 \%$, while only slightly affecting the production by $-7-3 \%$. By closing the yield gaps in water-rich regions, the national rice loss could be reduced from $10 \%$ to $7 \%$, whereas closing the harvest area gaps would fully compensate for the loss in production. This finding indicates that converting single-rice systems to double-rice systems in suitable regions (Scenario 2) has substantially greater potential to increase rice production than closing yield gaps. The double-rice systems accounted for $66 \%$ of the national harvest rice area in the 1980 s, whereas they currently represent less than $40 \%$ (Deng et al., 2019). One of the major divers of this change is the decreasing rural labor and rising labor costs, which lead to a lower net income from double-rice systems than from single-rice systems (Chen et al., 2013). Thus, more and more cropland has been converted from a double-rice to a single-rice system, termed "double to single". On the contrary, rice cropping expanded in some water-scarce northern regions during the past decades (Huai et al., 2019). However, from the perspectives of both food and water security, it is necessary to make full use of the existing suitable land for double-rice production instead of exploring new arable land, particularly in water-scarce regions. The rice production capacity of converted "double to single" paddy fields was estimated to be 1.7 times the target for newly cultivated land in China's land consolidation plan for 2016-2020; in addition, the full use of the converted "double to single" paddy fields can save 167 billion yuan (RMB) in newly reclaimed cultivated land costs (Jiang et al., 2019). Given China's growing awareness of the environmental impact of agricultural production, it appears possible to implement related measures to reach sustainable water use and grain production goals. Regional adjustments in cropping structure for water scarcity mitigation have already been successfully implemented by measures such as providing a certain number of subsidies to steer farmers' cropping practices (Huang et al., 2019a). Similarly, subsidies could encourage farmers to practice double-rice cropping rather than single-rice cropping in suitable regions. Our research provides detailed spatial information to support such decisions.

\section{Conclusions}

As many countries in the world face the challenges of water and food security, where and how food production occurs has emerged as an important concern. This study uses China's rice production as a case study to address the water-food nexus. We demonstrate the high potential for sustainable rice production by exploring opportunities in water-rich regions. Food production should carefully consider the regional water scarcity background. It is necessary to avoid aggravating unsustainable water consumption, which often occurs in regions of high water scarcity. To reach the downscaled water use boundary, rice redistribution is urgent and possible. By scenario analysis, we identified that there is substantial potential to balance rice production and water use by closing both the yield and harvest area gaps in water-rich regions (Scenario 3). Particularly, converting the current single-rice systems to double-rice systems shows high potential (Scenario 2). National policies on land use are advised to encourage the promotion of rice production in 
water-rich regions that are suitable for double-rice cropping. Using rice production as a case study, we demonstrate the broader value of integrating food production with a water use boundary for sustainable development.

\section{Declaration of Competing Interest}

The authors declare that they have no known competing financial interests or personal relationships that could have appeared to influence the work reported in this paper.

\section{Acknowledgments}

This work was supported by China's National Key Research and Development Program (grant number 2016YFD0300210); and the National Natural Science Foundation of China (grant number 31601269). We thank Dr. Nanyan Deng and Professor Jianliang Huang from Huazhong Agricultural University for providing the map on the boundary of double-rice systems and their valuable comments on the manuscript.

\section{Appendix A. Supporting information}

Supplementary data associated with this article can be found in the online version at doi:10.1016/j.agwat.2020.106602.

\section{References}

Chen, F.B., Pandey, S., Shijun, D., 2013. Changing rice cropping patterns: evidence from the yangtze River Valley, China. Outlook Agric. 42, 109-115. https://doi.org/ 10.5367/oa.2013.0126.

Davis, K.F., Rulli, M.C., Seveso, A., D’Odorico, P., 2017. Increased food production and reduced water use through optimized crop distribution. Nat. Geosci. 10, 919-924. https://doi.org/10.1038/s41561-017-0004-5.

Deng, N.Y., Grassini, P., Yang, H.S., Huang, J.L., Cassman, K.G., Peng, S.B., 2019. Closing yield gaps for rice self-sufficiency in China. Nat. Commun. 10,1-9. https://doi.org/ 10.1038/s41467-019-09447-9.

Diffenbaugh, N.S., Swain, D.L., Touma, D., Lubchenco, J., 2015. Anthropogenic warming has increased drought risk in California. Proc. Natl. Acad. Sci. U. S. A. 112, 3931-3936. https://doi.org/10.1073/pnas.1422385112.

Döll, P., Siebert, S., 2002. Global modeling of irrigation water requirements. Water Resour. Res. 38, 8-1-8-10. https://doi.org/10.1029/2001wr000355.

Huai, H., Chen, X., Huang, J., Chen, F., 2019. Water-scarcity footprint associated with crop expansion in Northeast China: a case study based on aquacrop modeling. Water 12, 125. https://doi.org/10.3390/w12010125.

Huang, J., Ridoutt, B.G., Sun, Z.X., Lan, K., Thorp, K.R., Wang, X.H., Yin, X.G., Huang, J. L., Chen, F., Scherer, L., 2020. Balancing food production within the planetary water boundary. J. Clean. Prod. 253, 119900 https://doi.org/10.1016/j. jclepro.2019.119900.

Huang, J., Ridoutt, B.G., Thorp, K.R., Wang, X.C., Lan, K., Liao, J., Tao, X., Wu, C.Y., Huang, J.L., Chen, F., Scherer, L., 2019a. Water-scarcity footprints and water productivities indicate unsustainable wheat production in China. Agric. Water Manag. 224, 105744 https://doi.org/10.1016/j.agwat.2019.105744.

Huang, J., Scherer, L., Lan, K., Chen, F., Thorp, K.R., 2019b. Advancing the application of a model-independent open-source geospatial tool for national-scale spatiotemporal simulations. Environ. Model. Softw. 119, 374-378. https://doi.org/10.1016/j. envsoft.2019.07.003.

, 2019International Food Policy Research Institute, 2019. Global Spatially-Disaggregated Crop Production Statistics Data for 2010 Version 1.1, doi: 10.7910/DVN/PRFF8V.

Jiang, M., Li, X., Bin, Xin, L.J., Tan, M.H., 2019. Paddy rice multiple cropping index changes in Southern China. J. Geogr. Sci. 29, 1773-1787. https://doi.org/10.1007/ s11442-019-1689-8.

Li, Z.G., Liu, Z.H., Anderson, W., Yang, P., Wu, W., Bin, Tang, H.J., You, L.Z., 2015. Chinese rice production area adaptations to climate changes, 1949-2010. Environ. Sci. Technol. 49, 2032-2037. https://doi.org/10.1021/es505624x.

Liu, X.H., Chen, F., 2005. Farming Systems in China. China Agriculture Press, Beijing, China.

Liu, Z.H., Li, Z.G., Tang, P.Q., Li, Z.P., Wu, W., Bin, Yang, P., You, L.Z., Tang, H.J., 2013. Change analysis of rice area and production in China during the past three decades. J. Geogr. Sci. https://doi.org/10.1007/s11442-013-1059-x.

Liu, Z.H., Yang, P., Tang, H.J., Wu, W., Bin, Zhang, L., Yu, Q.Y., Li, Z.G., 2015. Shifts in the extent and location of rice cropping areas match the climate change pattern in
China during 1980-2010. Reg. Environ. Change. 15, 919-929. https://doi.org/ 10.1007/s10113-014-0677-x.

Lobell, D.B., Cassman, K.G., Field, C.B., 2009. Crop yield gaps : their importance, magnitudes and causes. Annu. Rev. Environ. Resour. 34 (1), 179-204. https://doi. org/10.1146/annurevfienviron.041008.093740.

Lu, X.H., Wu, L.H., Pang, L.J., 2009. Effects of soil moisture on water utilization characteristics of rice (Oryza sativa). Chin. J. Rice Sci. 23, 186-190.

Mbava, N., Mutema, M., Zengeni, R., Shimelis, H., Chaplot, V., 2020. Factors affecting crop water use efficiency: a worldwide meta-analysis. Agric. Water Manag. 228, 105878 https://doi.org/10.1016/j.agwat.2019.105878.

Mueller, N.D., Gerber, J.S., Johnston, M., Ray, D.K., Ramankutty, N., Foley, J.A., 2012. Closing yield gaps through nutrient and water management. Nature 490, 254-257. https://doi.org/10.1038/nature11420.

Peng, S., Xu, J., Huang, Q., Wu, H., 2006. Experimental study on leaf water use efficiency of paddy rice under controlled irrigation. Trans. Chin. Soc. Agric. Eng. 22, 47-52.

Pfister, S., Koehler, A., Hellweg, S., 2009. Assessing the environmental impacts of freshwater consumption in LCA. Environ. Sci. Technol. 43, 4098-4104. https://doi. org/10.1021/es802423e.

Raes, D., Steduto, P., Hsiao, T.C., Fereres, E., 2009. Aquacrop-The FAO crop model to simulate yield response to water: II. Main algorithms and software description. Agron. J. 101, 438-447. https://doi.org/10.2134/agronj2008.0140s.

Ridoutt, B.G., Pfister, S., 2010a. Reducing humanity's water footprint. Environ. Sci. Technol. 44, 6019-6021 https://doi.org/10.102/es101907z.

Ridoutt, B.G., Pfister, S., 2010b. A revised approach to water footprinting to make transparent the impacts of consumption and production on global freshwater scarcity. Glob. Environ. Change 20, 113-120. https://doi.org/10.1016/j. gloenvcha.2009.08.003.

Rockström, J., Steffen, W., Noone, K., Persson, Å., Chapin III, F.S., Lambin, E., Lenton, T., Scheffer, M., Folke, C., Schellnhuber, H., Nykvist, B., de Wit, C., Hughes, T., Van der Leeuw, S., Rodhe, H., Sörlin, S., Snyder, P., Costanza, R., Svedin, U., Foley, J., 2009. Planetary boundaries: exploring the safe operating space for humanity. Ecol. Soc. 14 https://doi.org/10.5751/ES-03180-140232.

Rodda, J.C., 2004. World water resources at the beginning of the twenty-first century. Choice Rev. Online 41, 41-4063. https://doi.org/10.5860/choice.41-4063.

Scherer, L., Pfister, S., 2016. Dealing with uncertainty in water scarcity footprints. Environ. Res. Lett. 11, 1-9. https://doi.org/10.1088/1748-9326/11/5/054008.

Steduto, P., Hsiao, T.C., Raes, D., Fereres, E., 2009. AquaCrop-the FAO Crop Model to simulate yield response to water: I. Concepts and underlying principles. Agron. J. 101, 426. https://doi.org/10.2134/agronj2008.0139s.

Steffen, W., Richardson, K., Rockström, J., Cornell, S.E., Fetzer, I., Bennett, E.M., Biggs, R., Carpenter, S.R., Vries, W., De, Wit, C.A., De, Folke, C., Gerten, D., Heinke, J., Mace, G.M., Persson, L.M., Ramanathan, V., Reyers, B., Sörlin, S., 2015. Planetary boundaries : guiding changing planet. Science 347, 1-10. https://doi.org/ 10.1126/science.1259855.

Sun, H.Y., Zhang, X.Y., Wang, E.L., Chen, S.Y., Shao, L.W., 2015. Quantifying the impact of irrigation on groundwater reserve and crop production - a case study in the North China Plain. Eur. J. Agron. 70, 48-56. https://doi.org/10.1016/j.eja.2015.07.001.

Thorp, K.R., Bronson, K.F., 2013. A model-independent open-source geospatial tool for managing point-based environmental model simulations at multiple spatial locations. Environ. Model. Softw. 50, 25-36. https://doi.org/10.1016/j. envsoft.2013.09.002.

Tian, F., Yang, Y.H., Han, S.M., 2009. Using runoff slope-break to determine dominate factors of runoff decline in Hutuo River Basin, North China. Water Sci. Technol. 60, 2135-2144. https://doi.org/10.2166/wst.2009.578.

Vanuytrecht, E., Raes, D., Steduto, P., Hsiao, T.C., Fereres, E., Heng, L.K., Garcia Vila, M., Mejias Moreno, P., 2014. AquaCrop: FAO's crop water productivity and yield response model. Environ. Model. Softw. 62, 351-360. https://doi.org/10.1016/j. envsoft.2014.08.005.

Wieder, W.R., Boehnert, J., Bonan, G.B., Langseth, M., 2014. Regridded Harmonized World Soil Database v1.2. ORNL DAAC, Oak Ridge, Tennessee, USA. https://doi.org/ 10.3334/ORNLDAAC/1247.

Wu, W., Bin Q.Y., Yu, You, L.Z., Chen, K., Tang, H.J., Liu, J.G., 2018. Global cropping intensity gaps: Increasing food production without cropland expansion. Land Use Policy 76, 515-525. https://doi.org/10.1016/j.landusepol.2018.02.032.

You, L., Wood, S., Wood-Sichra, U., Wu, W., 2014. Generating global crop distribution maps: from census to grid. Agric. Syst. 127, 53-60. https://doi.org/10.1016/j. agsy.2014.01.002.

You, L.Z., 2012. A tale of two countries: spatial and temporal patterns of rice productivity in China and Brazil. China Econ. Rev. 23, 690-703. https://doi.org/10.1016/j. chieco.2010.10.004.

Yu, Q.Y., Wu, W., Bin, You, L.Z., Zhu, T.J., van Vliet, J., Verburg, P.H., Liu, Z.H., Li, Z.G., Yang, P., Zhou, Q.B., Tang, H.J., 2017. Assessing the harvested area gap in China. Agric. Syst. 153, 212-220. https://doi.org/10.1016/j.agsy.2017.02.003.

Zhang, Y.C., Lei, H.M., Zhao, W.G., Shen, Y.J., Xiao, D.P., 2018. Comparison of the water budget for the typical cropland and pear orchard ecosystems in the North China Plain. Agric. Water Manag. 198, 53-64. https://doi.org/10.1016/j. agwat.2017.12.027.

Zwart, S.J., Bastiaanssen, W.G.M., 2004. Review of measured crop water productivity values for irrigated wheat, rice, cotton and maize. Agric. Water Manag. 69, 115-133. https://doi.org/10.1016/j.agwat.2004.04.007. 